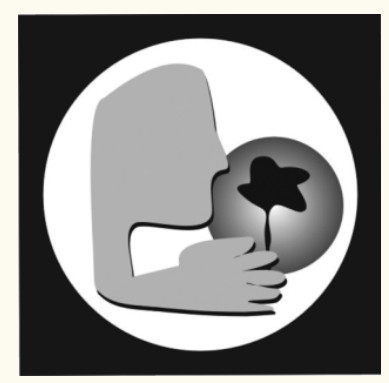

Sustentabilidade e $m$ Debate

\section{Sustainable Farming Systems in the Sub-Sahelian Zone of Burkina Faso - Key Factors}

\author{
E. Hien ${ }^{1 *}$, W.T. Kabore' ${ }^{1}$, D. Masse ${ }^{2}$, P. Dugue ${ }^{3}$ \\ ${ }^{1}$ Université de Ouagadougou, UFR/SVT, 03 BP 7021, Ouagadougou 03, \\ Burkina Faso Tel.: + (226) 702636 36. E-mail: edmond.hien@ird.fr \\ ${ }^{2}$ LEMSAT (IRD-ISRA-UCAD) Campus Bel-Air B.P. \\ 1386 CP 18524, Dakar - Sénégal \\ ${ }^{3}$ CIRAD TERA, BP 34398, Montpellier. Cedex 01, France \\ *Corresponding author
}

\begin{abstract}
Rapid population growth and climatic change threatens the sustainability of natural resources. Farming practices can mitigate environmental change and degradation. The aim of this research conducted in Yatenga region was to describe and to analyse manure practices management. In 2005, a survey was carried out to assess the evolution of farming practices. A survey was initially conducted with a sample of 44 farmers, selected randomly in the three neighbouring villages. Subsequently, 18 farms were selected for in-depth interviews. The grain yield was measured and the different practices of soil and water conservation developed by farmers were compared. According to the enquiries, two practices, called "zaï" and "djengo", were largely used in cereals production. The "zaï" practice, known as a traditional technique for restoration of degraded soil, is characterized by the capture of runoff by micro-watersheds and a localized organic matter supply at the soil-plant system scale. The "djengo" practice is based on the same principle of the "zaï" practice but was applied on the sandy soil as traditionally "zaï" concerned the degraded and crusty soils. The two practices could increase grain crop production but moreover could limit the risk of crops failure. In addition, our observations also showed that frequent tree regenerations occurred in plots and watersheds where "zaî" or "djengo" practices were used. This study highlights the necessity of better controlling soil, water and organic matter to improve agrosystem sustainability in sub Saharan Africa.
\end{abstract}

Key-words: Farming practices, soil and water conservation, sustainability, zaï, West Africa 


\section{Sustentabilidade em Debate}

\section{Introduction}

In the Northern region of West Africa, the climate is characterised by two contrasted seasons with a rainy season lasting 3 to 5 months. The temperature is high during the whole year, including the rainy season. Soils, according to the FAO classification, are generally Lixisol. These soils show a coarse texture in the topsoil and are prone to crust formation, favouring runoffs and water loss (Lal, 2000; Valentin et al., 2004).

Characterised by a superficial crust, these degraded soils are named "zipellé" (Marchal, 1983 ) in Mossi language, meaning "white soil”. Due to climatic and anthropogenic causes, soil degradation in the Yatenga region has involved the formation of large stripped glacis of worrying importance (Dugué, 1986). During years of continued droughts, many peasant families have been compelled to leave their villages and to settle in other regions within Burkina Faso, where rainfall levels are higher (McMillan et al., 1990). They have also settled in coastal countries, particularly in Ivory Coast, while others have been attracted to urban centres (Reij \& Thiombiano, 2003). These dynamics illustrate the relations between population and the environment, such as conceptualised by the neo-Malthusians, contrary to those developed by Boserup (1970). The first indicates that the increase in population leads to land degradation and to the loss of soil productivity, both of which can be decreased through migration. On the other hand, Boserup (1970) suggests adapting farming practices to natural resources (soil, vegetation) and new pedoclimatic and socio-economic conditions in order to lessen soil productivity decay. These changes of practices, based on soil and water conservation and intensification of the farming syste$\mathrm{ms}$, make it possible to maintain or to restore agricultural production to support rural populations.
The management of soil fertility in Yatenga is largely based on the recycling of organic matter resources produced within the agroecosystems. The determinants of the viability of such systems are the crop-fallow rotation and the maintenance of soil fertility by transferring organic matter from livestock or domestic wastes to cropped land. Any disturbance that modifies the balance between organic resources production and consumption will increase the risk of depletion of the viability of these systems (Manlay et al., 2004; Tittonell et al., 2007). According to the high rate of population growth, more than 3\% per year for the last decades, the needs for food production is increasing. Higher pressure on land leads to the decrease of natural resources production, provoking a reduction of the time of fallows. Livestock has to go further distances to feed, moving even outside the agrosystem. All this leads to the depletion of soil fertility and is sometimes accompanied by heavy soil degradation in a context of increasing extreme climatic events (Floret and Pontanier, 2000). The systems have become more vulnerable to climatic changes, as it was already the case during the great drought of the seventies.

The question was: How do the farmers react to these changes? And more particularly: Did they adapt their practices to those changes? To answer that question, we proposed an enquiry in a village that had been observed in the past - during the $80 \mathrm{~s}$ and $90 \mathrm{~s}$ - and sought to identify the changes in the villagers' farming practices. Particularly, we focused on the changes in soil fertility and water management. Our hypothesis was that the particular practices of soil and water conservation developed by farmers during the two precedent decades fitted well with the concept of "ecological engineering", as defined by Odum and Odum (2003): “The study and practice of fitting environmental technology with ecosystems self 
design for maximum performance". Moreover, these technologies referred to conceptual and ecological characteristics of the savannah ecosystem in West Africa.

\section{Materials and Methods}

\subsection{Study Area}

This study was conducted in Ziga $\left(13^{\circ} 25^{\prime} \mathrm{N}\right.$, $\left.2^{\circ} 19^{\prime} \mathrm{W}\right)$, a village located in the Yatenga province of Northen Burkina Faso (Figure 1). The village is densely populated (70-100 dwellers/ha) by the Mossi, Fulani and Dogon ethnic groups. The region is characterised by an erratic rainfall distribution with an annual rainfall average of 400 to $800 \mathrm{~mm}$. Annual rainfall averages decreased continuously from 1921 until 1990, when a small improvement was observed. Soils are mainly classified as ferric leptosols (FAO, 1998). They are generally not very deep and poor in organic matter.

\subsection{Method}

Selection of the Studied Farms

At the initial state of this study, a survey was conducted with a sample of 44 farmers that were randomly selected in the three neighbouring villages of Bossomboré-Yakin (BY), Biingwéogo (BW) and Légoum (LG). Farms were classified according to their input use. Selection criteria were: (i) plot area and manpower; (ii) herd size and manure availability; (iii) farm equipment. Eighteen farms were subsequently selected for in-depth interviews. Among them, nine were well-tended (following their input level) and nine unkempt. Farms in-between were excluded.

\section{Survey}

The survey required several visits to each farm $(2,3,4)$. The main topics treated during the interviews are summarized as follows:

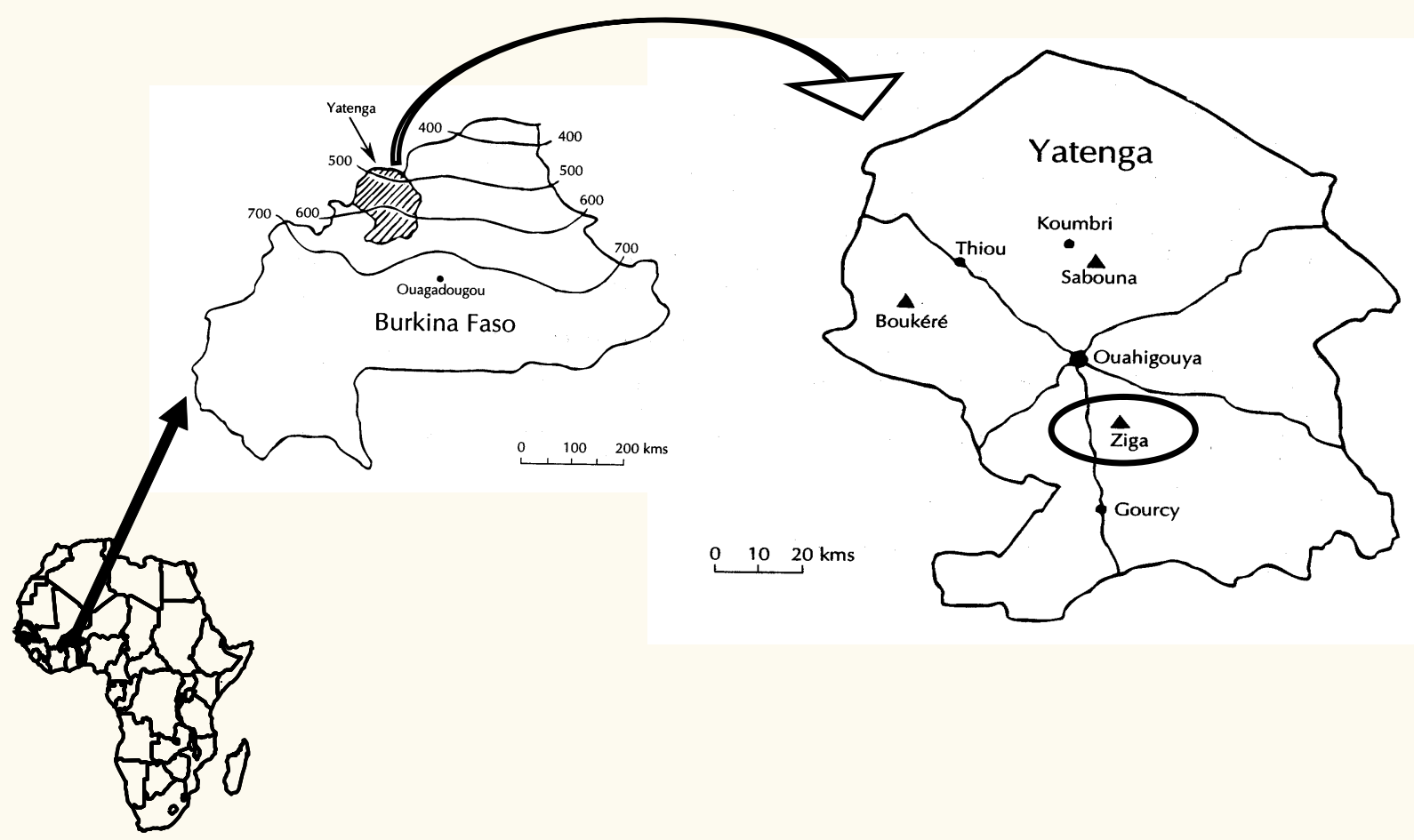

Figure 1. Study Area Location 
- Farm assets: e.g. crops plots, equipments, livestock production

- Manuring and other Soil and Water Conservation (SWC) practices;

- Farm yield assessment in 2005 according to each manure practice.

\section{Assessment of manure practices}

To assess the manure practices, we placed squares of $9 \mathrm{~m}^{2}(3 \mathrm{~m} \times 3 \mathrm{~m})$ on various plots that were representative of different crop management sequences with manuring and SWC practices, such as zaï, djengo, and till or no-till practices with direct sowing. The following parameters on zaï and djengo practices were considered:

- Zaï or djengo hole shape (width, depth, diameters);

- Manure quantity (dry matter /ha) ;

- Zaï or djengo holes density and the time of work to settle one hectare of these practices.

The effects on crop production of the different cultural practices were assessed by yields and their components' measurement.

All analyses were compared with the analysis of variance (ANOVA) and mean values through the Newman- Keuls test (SNK), with a confi- dence level of $\mathrm{P}<0.05$. All analysis were performed with XLSTAT 7.5 (ADDINSOFT (C).

\section{Results}

\subsection{Farm characteristics}

Results show that large farms had an average of 6,3 ha against 3,7 ha for the small ones. Field dimensions varied according to the districts: it decreased gradually from LG to BW and finally to BY, where cultivated areas were tiny. The number of workers per farm varied from 9 to 14 for large farms to 3 to 6 for the small ones. On average, large farms had 2 or 3 times more workers than the small ones.

The cultivated area per worker was higher on small farms than on large ones, irrespective of the agricultural district. Considered from the large farms to the small ones, these values were respectively: 0,5 ha and 0,93 ha (BY), 0,63 ha and 1,15 ha (BW), 0,57 ha and 0,72 ha (LG).

Large farms had more animals than the small ones, as it was observed in the BY district, where farms owned more than 15 cattle, 15 sheep and goats each one (Figure 2). Small farms had no cattle and only a few sheep and goats (less than 5).

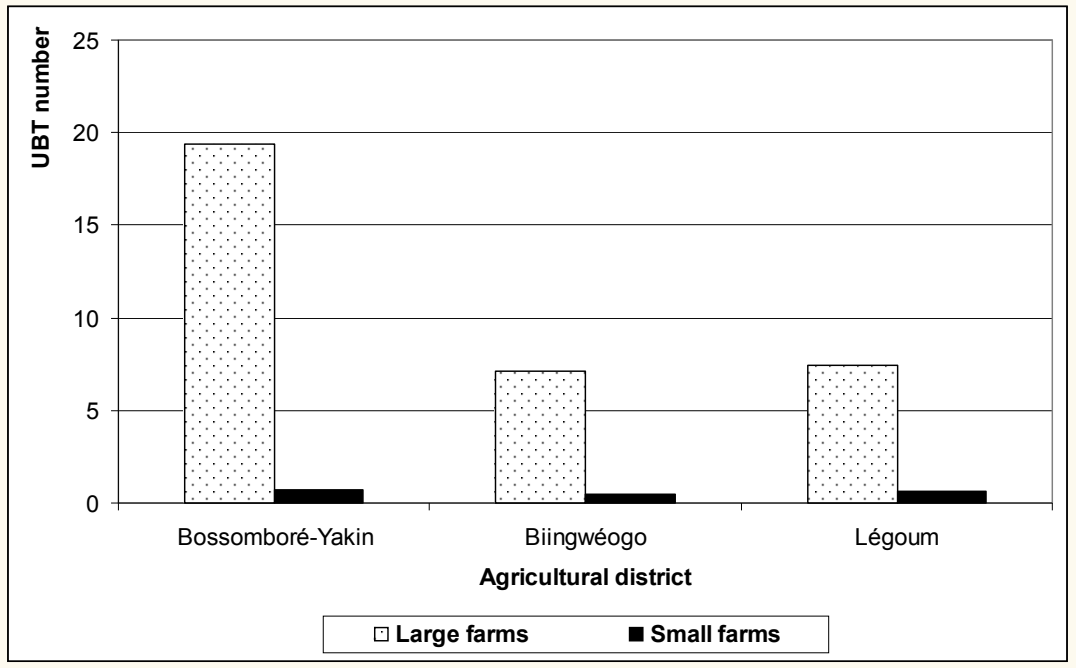

Figure 2. Manure Potential and Livestock Number per Agricultural District (UBT=Tropical Cattle Unit) 
The potential manure per farm was very variable and depended on cattle availability (Figure 2). Some farms had a potential production of almost $22 \mathrm{t}$. per year while others had less than $1 \mathrm{t}$. per year.

\subsection{The "zaï" Practice}

In the Moore language, "zaï" was derived from the word "zaïegré", which meant: "Wake up early to prepare the seedbed". The baseline principle of zaï is: holes are dug before the onset of the rainy season and manure is put into the hole at the end of the dry season. The distribution of the holes on the field was done to catch the maximum of the rain runoff. $53 \%$ of farmers practiced the zaï according to these rules. However, there was a large variability regarding the dates of digging of the holes and the options of sowing to supply manure or not (Figure 3 ).

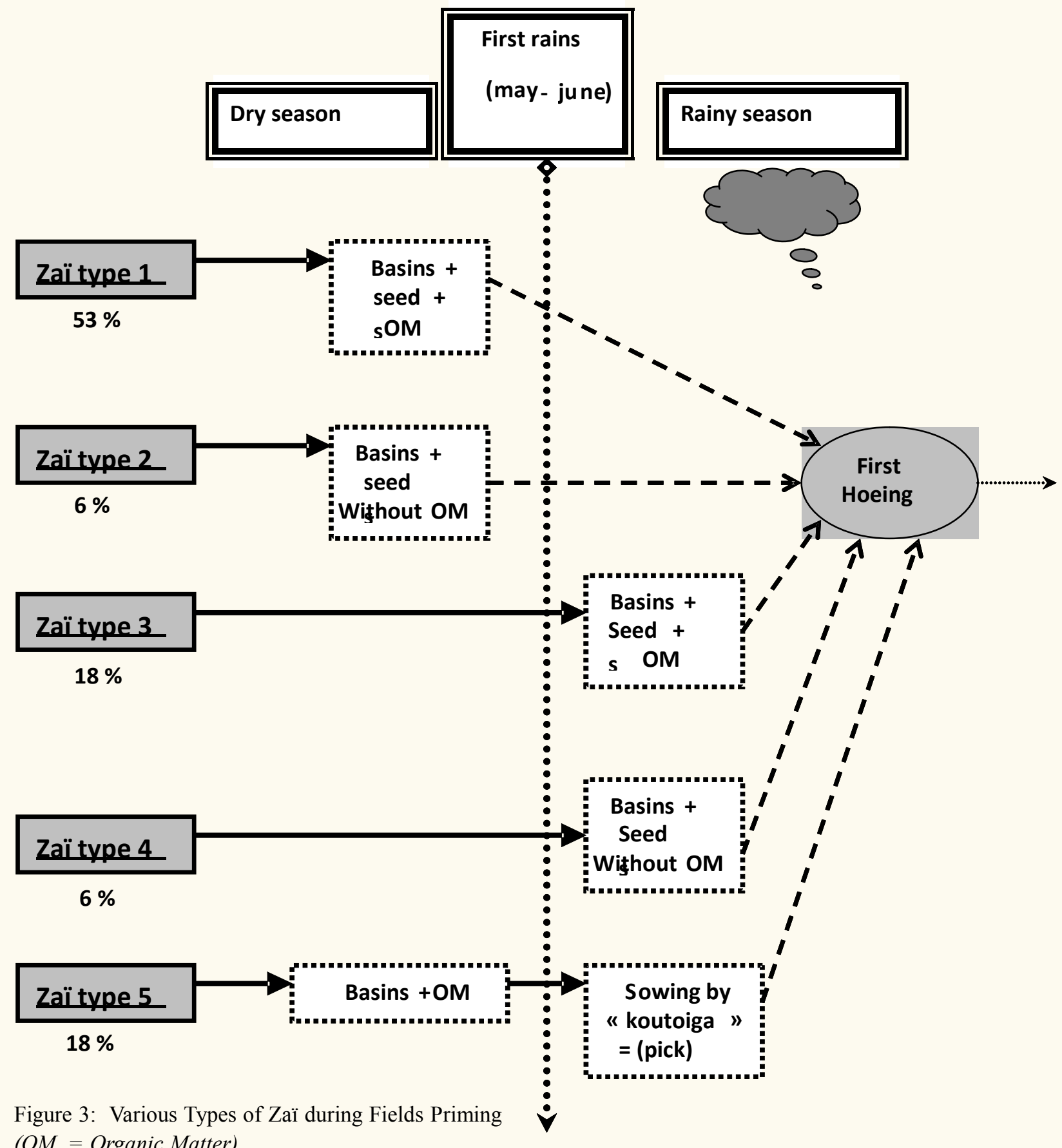


The availability of work force and of manure was another factor that influenced the diversity of the zaï practice.

Another factor of variability of the zaï practices was the frequency of the zaï technique in the cropping system:

- $37,5 \%$ of farmers practiced the zaï every year on the same plots. The holes of the previous year were not necessarily the same of the following year. The holes were randomly positioned;

- $37,5 \%$ of surveyed peasants made zaï every year in a permanent way by using continuously the same basins for several years. In this case, each year, year n-1 basins are re-opened and manure brought again;

- $12,5 \%$ of farmers made zaï every two years, preserving the same holes on the field. After the zaï practice on the year $\mathrm{n}$, the farmers used the direct sowing in year $\mathrm{n}+1$;

- $6,25 \%$ of peasants practiced the zail two over three years, using the same holes for the two years of zaï. After two years of successive zaï practice, they proceeded on the third year of a direct sowing for one year and reverted to zaï practice for two years, and so on.

- The last type of practice (corresponding to $6,25 \%$ of surveyed farmers) concerned farmers who practiced the zaï every year and used the crop residues produced the year $n-1$ as mulch on the space between the holes that had not tilled with the zaii practice. The objective of the farmers was to promote the soil restoration of the field. In this case, the holes' localization remained fixed from one year to another.
Table 1 describes some parameters of cultivated plots with sorghum according to zaï practice. Hole density was $23.210 \mathrm{ha}^{-1}$ on large farms against $33.889 \mathrm{ha}^{-1}$ for small ones. Sixty-eight days and fifty-two days were necessary for a worker to dig one hectare of zaï, respectively on large and small farms. In addition, zaï basin holes were significantly different from large to small farming systems, with small diameter measuring $32,9 \mathrm{~cm}$ and $23,5 \mathrm{~cm}$ for large and small farms respectively. Large diameter was $36,4 \mathrm{~cm}$ and $26,6 \mathrm{~cm}$ respectively for large and small farms. The depth of the hole was $10,6 \mathrm{~cm}$ for large far$\mathrm{ms}$ and $10,3 \mathrm{~cm}$ for the small ones. Differently from the small farms, large farms tended to accommodate bigger size holes. Like hole dimension, manure quantity in zaï basins was higher in big farms with a high production of manure. On average, 542 g per hole were applied on large farms against only $230 \mathrm{~g}$ per hole on small-scale farms, which corresponds to 12,6 t.ha $^{-1}$ and 7,8 t.ha ${ }^{-1}$, respectively.

Djengo, another practice in the use of manure

The other SWC practice, called "djengo", is similar to zaï and was observed in Ziga. This technique was not noticed in the precedent studies in Yatenga region. The djengo is a hand tool similar to a hoe with long handle, which is used to carry out the practice bearing the same name. Djengo was practiced on sandy soils and exclusively after the beginning of the rainy season. There were also several alternatives to the djengo practice. A majority of farmers $(60 \%)$ did not till and waited for the growth of the first weeds to dig the holes instead; other farmers ploughed the soil before digging large holes. The quantity of manure applied also varied among farmers.

As the hole was not maintained in sandy soils during the rainy season, the localization of the 
Table 1. Characteristics of Zaï and Djengo Practices

\begin{tabular}{|c|c|c|c|c|c|c|c|c|}
\hline Practice & Farms & $\begin{array}{l}\text { holes density } \\
\text { (number/ha) }\end{array}$ & $\begin{array}{l}\text { Time for } \\
\text { laying } \\
\text { out } 1 \text { ha } \\
\text { (days/ha) }\end{array}$ & $\begin{array}{l}\text { Diameter } 1 \\
(\mathrm{~cm})\end{array}$ & $\begin{array}{l}\text { Diameter } 2 \\
(\mathrm{~cm})\end{array}$ & $\begin{array}{c}\text { Basin } \\
\text { depth } \\
(\mathrm{cm})\end{array}$ & $\begin{array}{c}\text { Manure } \\
\text { quantity per } \\
\text { hole } \\
(\mathrm{g})\end{array}$ & $\begin{array}{c}\text { Manure } \\
\text { quantity } \\
\text { (t/ha) }\end{array}$ \\
\hline \multirow{4}{*}{ Zaï } & $\mathrm{LF}$ & 23210 & 68 & $32.9^{\mathrm{a}}$ & $36.4^{\mathrm{a}}$ & $10.6 \mathrm{a}$ & $542 a$ & 12.57 \\
\hline & $\mathrm{CV}(\%)$ & & & 7.0 & 6.1 & 9.8 & & \\
\hline & SF & 33889 & 52 & $23.5^{\mathrm{b}}$ & $26.6^{\mathrm{b}}$ & $10.3 b$ & $230 \mathrm{~b}$ & 7.77 \\
\hline & $\mathrm{CV}(\%)$ & & & 5.9 & 6.3 & 9.5 & & \\
\hline \multirow{4}{*}{ Djengo } & $\mathrm{LF}$ & 41481 & 15 & $26.9^{\mathrm{a}}$ & $26.7^{\mathrm{a}}$ & $7.0^{\mathrm{a}}$ & $211.1^{\mathrm{a}}$ & 8.76 \\
\hline & $\mathrm{CV}(\%)$ & & & 11.1 & 9.0 & 15.5 & 12.8 & \\
\hline & $\mathrm{SF}$ & 38889 & 24 & $22.5^{\mathrm{a}}$ & $27.1^{\mathrm{a}}$ & $8.3^{\mathrm{b}}$ & $173.4^{\mathrm{a}}$ & 6.74 \\
\hline & CV (\%) & & & 8.9 & 5.5 & 9.0 & 6.6 & \\
\hline
\end{tabular}

LF: Large farms; SF: Small farms; CV: Coefficient of Variance

Numbers followed by the same letter in a column are not statistically different $(P<0,05)$ for the same practice

holes in the djengo practice was changed every year. The number of holes per hectare was relatively constant between the farmers' fields ( 38.889 to 41.481 basins.ha ${ }^{-1}$, respectively for large and small farms) and the time of the field preparation was of 15 to 24 days.ha $^{-1}$, respectively for large and small farms (Table 1). In the same way, hole sizes in djengo were not significantly different between the two types of farms: (i) small diame- ters: $26,7 \mathrm{~cm}$ and $22,5 \mathrm{~cm}$; (ii) large diameters: $26,9 \mathrm{~cm}$ and $27,1 \mathrm{~cm}$ and finally (iii) depths: 7,7 $\mathrm{cm}$ and $8,3 \mathrm{~cm}$. The quantities of applied manure in djengo reached 8,8 t.ha $^{-1}$ on large farm vs. 6,7 t.ha ${ }^{-1}$ in small ones.

The differences between zaï and djengo are synthesized in Table 2. Zaï and djengo differ mostly by the used tools. The tool used for digging zaï holes is called "boamboara" and has a short,

Table 2. Summary of Key Differences between Zaï and Djengo Practices

\begin{tabular}{|c|c|c|}
\hline Elements of difference & Zaï practice & Djengo practice \\
\hline Tools & Boamboara & Djengo \\
\hline Basins density & $27481^{\mathbf{a}}$ & $39753^{\mathbf{b}}$ \\
\hline Time for laying out 1ha & $62^{\mathbf{a}}$ & $21^{\mathbf{b}}$ \\
\hline Basin diameter 1 (cm) & $31,3^{\mathbf{a}}$ & $25,8^{\mathbf{b}}$ \\
\hline Basin diameter 2 (cm) & $35,1^{\mathbf{a}}$ & $26,8^{\mathbf{b}}$ \\
\hline $\begin{array}{c}\text { Basin depth } \\
\text { Manure quantity } \\
\text { (g/basin) }\end{array}$ & $10,9^{\mathbf{a}}$ & $7,4^{\mathbf{b}}$ \\
\hline $\begin{array}{c}\text { Manure quantity (t/ha) } \\
\text { Soil type }\end{array}$ & 417,3 & 185,7 \\
\hline Period & Mostly loamy soils & 7,4 \\
\hline
\end{tabular}

Numbers followed by the same letter on a row are not statistically different $(P<0,05)$

Source: Authors' 
curved handle with a blade, while the djengo has a longer handle. This difference in the handle length induces a difference in the worker position: to dig zaï holes, the worker bends down, while djengo is used in a stand up position. Zaï holes are larger than those of djengo, whatever the nature of the soil, implying that more manure is applied in zaï holes (Table 2). Zaï is generally carried out during the dry season and on massive and encrusted soils, while djengo is exclusively practiced on sandy soils and after the beginning of the rainy season.

\subsection{Assessment of the sorghum and millet} yields.

In 2005, we measured the crop yields on farm fields cropped or not through zaï or djengo practices. We noticed that the grain yield was not different when comparing these practices to the conventional tillage of soils. However, plant biomass was significantly higher in djengo or zaï plots. Sorghum and millet yield are correlated to the number of grains per panicle or per year (Table 3). There are no significant differences $(\mathrm{p}=$ $0,05 \%$ with SNK test) between grain yields produced with zaï, djengo and simple sowing (Table 4). However, the straw yields were significantly higher under direct sowing, both with zaï and djengo practices.

Because millet is produced on sandy soils, we compared only the millet yield between the djengo and the direct sowing practices. There is a slight increase of straw and grain yield under djengo when compared with the direct sowing (Table 5).

The first initiatives on soil and water conservation began in Ziga in the sixties, with the GERES program (1960-1964). GERES had a li-

Table 3. Pearson Correlation Test (Parametric Test) between Yield and its Components

\begin{tabular}{|c|c|c|c|c|}
\hline \multirow[b]{2}{*}{ Yield component } & \multicolumn{2}{|c|}{ Sorghum $(n=52)$} & \multicolumn{2}{|c|}{ Millet $(n=15)$} \\
\hline & $\begin{array}{l}\text { Correlation } \\
\text { Coefficient }\end{array}$ & $\mathrm{p}$-value bilateral & $\begin{array}{l}\text { Correlation } \\
\text { Coefficient }\end{array}$ & $\begin{array}{l}p \text {-value } \\
\text { bilateral }\end{array}$ \\
\hline Bunch number.ha ${ }^{-1}$ & -0.164 & 0.246 & -0.801 & 0.0001 \\
\hline Stems number.bunch ${ }^{-1}$ & 0.293 & 0.036 & 0.497 & 0.056 \\
\hline Ears number.stem ${ }^{-1}$ & 0.630 & $<0.0001$ & 0.103 & 0.715 \\
\hline Grains number.ear $^{-1}$ & 0.610 & $<0.0001$ & 0.753 & 0.001 \\
\hline Grain mass (g) & 0.277 & 0.048 & 0.38 & 0.162 \\
\hline
\end{tabular}

Table 4. Sorghum yield (grain and straw) and its components (mean \pm se) for different agricultural practices at Ziga, Burkina Faso. ANOVA and Newmans-Keuls means comparison test (means with the same letter belong to the same group)

\begin{tabular}{|c|c|c|c|c|c|c|c|c|}
\hline Variables & $\begin{array}{c}\text { Direct Sowing } \\
(n=20)\end{array}$ & & $\begin{array}{c}\text { Djengo } \\
(\mathrm{n}=9)\end{array}$ & & $\begin{array}{c}\text { Zai } \\
(n=23)\end{array}$ & & F Fischer & $P$ value \\
\hline Bunch number.ha $^{-1}$ & $31107 \pm 341$ & $a$ & $29336 \pm 200$ & $\mathrm{~b}$ & $28884 \pm 328$ & b & 13.4 & $<0.001$ \\
\hline Stems number.bunch ${ }^{-1}$ & $3.09 \pm 0.15$ & & $3.51 \pm 0.22$ & & $3.69 \pm 0.23$ & & 2.52 & 0.091 \\
\hline Ears number.stem ${ }^{-1}$ & $0.57 \pm 0.05$ & & $0.47 \pm 0.03$ & & $0.49 \pm 0.04$ & & 1.522 & 0.228 \\
\hline Grains number.ear $^{-1}$ & $716 \pm 69$ & $\mathrm{~b}$ & $920 \pm 127$ & $a b$ & $997 \pm 77$ & a & 3.54 & 0.037 \\
\hline Grain mass (g) & $0.023 \pm 0$ & & $0.021 \pm 0.001$ & & $0.021 \pm 0$ & & 2.68 & 0.079 \\
\hline Grain yield $\left(M \cdot h^{-1}\right)$ & $0.93 \pm 0.13$ & & $0.92 \pm 0.16$ & & $1.1 \pm 0.13$ & & 0.52 & 0.599 \\
\hline Straw yield $\left(\mathrm{Mg} \mathrm{ha}^{-1}\right)$ & $1.82 \pm 0.19$ & $\mathrm{~b}$ & $2.32 \pm 0.49$ & $a b$ & $2.96 \pm 0.35$ & a & 3.69 & 0.032 \\
\hline
\end{tabular}


Table 5. Millet yield (grain and straw) and its components (mean \pm se) for different agricultural practices at Ziga, Burkina Faso.

\begin{tabular}{lcccc}
\hline \multicolumn{1}{c}{ Variables } & $\begin{array}{c}\text { Djengo } \\
(\mathrm{n}=6)\end{array}$ & $\begin{array}{c}\text { Direct sowing } \\
(\mathrm{n}=9)\end{array}$ & F Fischer & P value \\
\hline Bunch number.ha $^{-1}$ & $31423 \pm 802$ & $32943 \pm 102$ & 5.39 & 0.037 \\
Stems number.bunch $^{-1}$ & $3.33 \pm 0.13$ & $2.78 \pm 0.14$ & 7.33 & 0.018 \\
Ears number.stem $^{-1}$ & $0.53 \pm 0.05$ & $0.62 \pm 0.05$ & 1.39 & 0.26 \\
Grains number.ear $^{-1}$ & $1350 \pm 293$ & $939 \pm 79$ & 2.62 & 0.13 \\
Grain mass (g) & $0.011 \pm 0.001$ & $0.012 \pm 0.001$ & 0.32 & 0.579 \\
Grain yield (Mg.ha $\left.{ }^{-1}\right)$ & $0.8 \pm 0.17$ & $0.59 \pm 0.06$ & 2.04 & 0.177 \\
Straw yield $\left({\left.\mathrm{Mg} . \mathrm{ha}^{-1}\right)}^{1.68 \pm 0.5}\right.$ & $1 \pm 0.11$ & 2.61 & 0.13 \\
\hline
\end{tabular}

mited success in comparison to the authorised investment and the negative effects of ridges made with soil. After the drought of 1984-1985, the research and development (R\&D) program was reoriented towards regional planning in the use of stone lines and grass bands. Some $18 \%$ of the village's cropped area was protected with stone lines between 1987 and 1990 (Dugué et al., 1993) with logistic and technical support of the R\&D program. According to the CORAF/ CRDI project (2002), $35 \%$ of the cropped area was conserved using stone lines. In 2005, $65 \%$ of the cropped area was managed with stone lines. In Ziga, tree regeneration is visible.

\section{Discussion}

The variation of the field dimensions indicates a stronger land pressure in BY. Large farms with their workers and equipment did not try to extend their cultivated areas. Workers on these farms worked on reduced areas. This could be interpreted as a sign of agricultural intensification.

We assume that one cow/bull was the equivalent of one tropical bovine unit (TBU), and a small ruminant 0.1 TBU. We also considered that 1 TBU produced one ton of dry matter of dung per year. If we consider a homogenous distribution of manure on every cropped area, the farms that could supply their fields with 5 tons per hectare of organic manure - which is the recommended dose by agricultural extension service-, were few. But, comparing cattle dung production on the farm and quantities of organic manure brought this year on the field, we noticed that all the farms use more manure than they can obtain from their own cattle manure. Farms have other sources of organic matter. In fact, most of the farmers collected organic matters produced on their farms and stored them in manure pits. The organic resources used were the manure of stalling animals, dung collected on grazing areas, household waste, crops residues and even some grass from the fallow area. Some farmers brought water in the manure hole and regularly mixed the organic matter to produce better compost. Composting is still rare, though.

The zaï technique is a traditional practice which is used in the Sahelian area to restore the degraded soils or for soils with physical properties in topsoil that do not allow the application of traditional tillage practices (i.e. crusting soils or stony soils). Zaï, a Mossi expression, derives from a word meaning "to wake up early". In fact, soil must be prepared a long time before the seedlings. Farmers dig microbasins (pits) to trap rains, sand, and organic residues transported by the wind. Then they bring manure or a mixture of organic matter coming from the farm and more 


\section{Sustentabilidade em Debate}

or less composted. Some studies showed that it is quite a complex system for soil restoration where soil fauna play a major role (Roose et $a l$., 1999). The technique was time consuming farmers. Moreover they rely on the availability of organic resources. These two constraints might impede the adoption by farmers.

Zaï is usually practiced on marginal soils, where it increases grain and straw production in comparison to those obtained through direct sowing and djengo techniques (often carried out on richer soils). Some argue that the zai technique favours production extensification because it fosters marginal soil cultivation.

At the cultivated plot, however, the zaï practice can be seen as an intensification of the farming system, since crops from previously unproductive soils can be more abundant than those obtained in soils usually considered more fertile. The stone lines building and the hole digging, as well as the organic matter and mineral fertilizers application and water pouring, require additional labour and capital intensification.

The djengo practice is based on the same principle than the zail technique. The main difference was that it is applied on more sandy soils that are not degraded. Djengo's goal is to create a microcatchment for runoff, mostly for the first rainfall, and to supply with organic products acting as fertilizers before the seeding. While the djengo technique is not really time-consuming, the availability of organic materials remains a key issue.

When asked about the factors leading to the success of the zaï technique, farmers highlighted the importance of the control of runoff at the scale of the fields and the watershed. This control was obtained by the stones lines, apparently a vital factor in this technique. Farmers also pointed out the availability of organic mat- ter as fertilizers. In Ziga, a large development of manure pits where all organic residues were collected to be stored and sometimes composted was observed. The organic residues came from livestock, domestic waste and even from noncultivated areas.

To be efficient, the zaii as well as the djengo techniques require large quantities of manure. For that, it is necessary to associate livestock production to agriculture production. Farmers should not only invest on rainwater management but also on increasing the animal manure production. Zaï production on marginal plots can reduce forage production. In Ziga, animal stalling on the farms was developed during the last 20 years to intensify animal production in response to the increasing urban demand for meat. More forage will be required in the future. The increase of the areas that are protected with stone lines reflects the steady and fast change of practices aimed at combatting water runoff and erosion.

Two decades ago, a research development (R \& D) project reported that it was necessary to control runoff and erosion to optimize rainwater use and to maintain soil fertility. The project proposed to extend the physical control of runo$\mathrm{ff}$ at the scale of micro watersheds, using stone lines, and the development of tillage practices using animal traction. It also proposed to increase the production and valorisation of organic resources as inputs, and the use of mineral fertilizers. Some traditional practices of restoration for degraded soil that could be described as "zaï" were reported. But those techniques were considered confidential. In 2005, we observed that there was a change in the relative importance of the cultivated plant in the crop rotation.

There were no zaï practices in the eighties (Marchal, 1983). The traditional practice was manual ridging, intended to bury weeds and to 


\section{Sustainable Farming Systems in the Sub-Sahelian Zone of Burkina Faso - Key Factors}

increase soil surface roughness in order to reduce runoff. In 1989, Dugué observed a small extension of zaï in Ziga but no djengo on sandy soils. $\mathrm{R}$ $\& D$ were focusing on mechanization and the use of mineral fertilizers to increase the crop production.

Twenty years later, our research confirmed the importance of zaï techniques in Ziga, confirmed by other studies such as the R3S project (2002), which indicated that $35 \%$ of the cultivated fields were tilled by zaï practices. The areas devoted to sorghum in the crop sequencing increased, whereas those of millet decreased. However, sorghum cropping demands more nutrients and water than millet does.

In the case of the village of Ziga, we observed that the proximity of the town of Ouahigouya stimulated the development of animal farming, with more sedentary livestock techniques, favouring manure availability.

The variability of the zaï practice was a response to environmental constraints such as soil poverty, erratic rainfalls, and the limited availability of organic matter and/or labour force.

The diversity of the zaï and djengo techniques pointed out in this study tends to confirm the capacity of farmers to improve their agricultural practices in response to climatic changes and population increase. As Mazzucato and Niemeyer (2000) showed in their study in Eastern Burkina Faso, the adaptation of the social organisation contributes to a great extent to the improvement of agricultural production after a phase of degradation following demographic and environmental changes. The social impacts of the evolution of natural resources management should be assessed by future studies in Ziga.

Vegetable growth was improved thanks to the use of zaï and djengo techniques, but water deficit at the end of the rainy season induced a depletion of grain yields. The higher demand of water in the djengo and zaï crop fields might explain the higher sensibility of these plants to water stress. It is worth remembering that farmers in the semi arid sub-Saharan region have to cope with an erratic rainfall level. Therefore, the objective of farmers' strategies in the region is to offset climatic risks by adopting adequate techniques. In this case, the major risk concerned seeding at the onset of the rainy season, since zaï and djengo practices were dedicated to capture the first rains.

Tree regeneration is a result of the changes in farmers' practices and of the various SWC interventions. Reij and Thiombiano (2003) have reported similar results in other Yatenga villages and shown an improvement of the agricultural outputs, a better management of soil fertility and tree regeneration with the development of soil and water conservation techniques.

It appears that there has been a significant change in agricultural practices in the sub-Sahelian village of Ziga, allowing the maintenance and even an improvement of cropping. SWC, associated with organic and mineral fertilization, seems to be decisive in this respect. The evolution of the farming systems indicated that the village of Ziga would present a Boserupian type of dynamic. Boserup (1970), considers that rural population growth in developing countries is favourable to food security because population pressure triggers agricultural intensification of labour and capital, as well as innovation.

At the scale of the farming system and the landscape, the zaii practice has led to an extension of cultivated surfaces. Farmers recognise that zaï demands much human effort to set cropping fields, but they also say once they have managed to settle the crops there is no need to till during the cropping season. In fact, and more 
particularly on the stony or crusty soils, the development of weeds around the holes is reduced, and tillage operations during the crop are limited. That is why stony or crusty land in Ziga has become a matter of economic speculation.

The environmental impact came from the association of water control at the scale of the watershed and the fields that allowed the regeneration of trees in the landscape. There was an outstanding example of savannah regeneration in the village of Gourga near Ziga, where a farmer rehabilitated a forest from degraded, completely bare soil. The farmer started with the application of zaï techniques where cereals were produced. This lasted from 3 to 4 years. During this period, the trees regenerated. After this period, the farmer stopped the cropping and the natural vegetation invaded the field. Twenty years later, this farmer had obtained a savannah landscape with almost a continuous tree canopy. The farmer controlled runoff and erosion by using local techniques, plant regeneration, and the withdrawal of woods and other plant products. This case was an example of ecological engineering where the initial zaï triggered the rehabilitation of the savannah. This is why this practice has been named "forest zai".

In short, zaï or djengo practices are based on soil, water, plant and nutrient management. The objective of this management is to increase nutrients for the plant. Other studies focused on savannah regions have arrived to similar conclusions. That is the case of the perennials grasses of the Lamto savannah (Ivory Coast), which developed a closed system, self sufficient in terms of nutrients through the application of a rapid recycling of root exudates in the rhizosphere. In this case, the nutrient resources were concentrated in plant systems after a period of organic accumulation (Abbadie et al., 1992; Lata et al.,
2000). The tiger bush of Niger is also a dynamic system based on the concentration of water resource or plant residues under the control of the biological activity and with the win and runoff as the vector of transport (Couteron et al., 2000; Guillaume et al., 2001). Studies on the dynamic of savannah vegetation define the concept of the Patch-dynamic hypothesis to explain the stable equilibrium persisting over millennia in arid savannahs where rainfall levels are erratic (Wiegand et al., 2006; Meyer et al., 2007). The authors considered that landscapes consist of a shifting mosaic of many patches in different states of transition between grassy and woody dominance involving an equilibrium of the status of the vegetation. Even in farming systems research, several studies have highlighted the farmer-driven resource use of efficiency gradients within farms. Indeed, farmers invest more effort and resources in the more productive and less risky fields within their farms (Tittonell et al., 2005a; Tittonell et al., 2005b). The analysis of the organic fluxes at the scale of the village showed that certain fields within the farm receive the major organic matter coming from livestock or domestic waste. The hypothesis was proposed that this patchy design of carbon fluxes could guarantee the viability of tropical agroecosystem (Manlay et al., 2004). Zaï practices and related practices as djengo are in line with the concepts of the patchiness pattern of resources to optimize plant production.

\section{Conclusion}

The zaii and djengo practices based on the control of water and organic fertilizers supply have been largely adopted in Ziga. It is possible to cultivate soils that were usually not used under traditional farming. Farm intensification of 
the farming systems using zaï and djengo practices is possible. In naturally poor tropical soils, the local supply of water and organic fertilizers is the main determinant of crop production in regions with erratic rainfall levels.

Rural population growth is not necessarily negative. It can foster agricultural intensification and innovation. Our research shows that innovations of agricultural practices occur and lead to an increase of agricultural yields and to an environmental regeneration that contributes to poverty reduction.

Finally, the development of these practices seems to be another evidence of the importance of the spatial organization of the determinant components that drive an ecological system. Our hypothesis is that the localization or concentration of resources in a poor environment is the most efficient organisational step to ensure the viability of a system. This should be further analysed under pedoclimatic conditions in order to contribute to the enhancement of soil fertility management and to the improvement of farming systems improvement savannahs agrosystems.

\section{References}

Abbadie L., A. Mariotti, and J.C. Menaut. Ecology v.73, n. 608, 1992.

Boserup E. Évolution agraire et pression démographique. Flammarion, Paris, 1970.

Couteron P., A. Mahamane, P. Ouedraogo, and J. Seghieri. J. Veg. Sci. v. 11 pp. 321-328, 2000. CORAF/CRDI. Activités de recherche conduites dans le cadre du projet R3S : intégration agriculture-élevage et gestion des ressources naturelles (campagne 2001-2002). Rapport technique, 2002.

Dugué, P. Programme de RechercheDéveloppement au Yatenga, programme d'agronomie : Rapport de synthèse 1984, 1986.

Dugué, P. Possibilités et limites de l'intensification des systèmes de culture vivriers en zone soudano-sahélienne : le cas du Yatenga (Burkina Faso). Extrait de thèse de l'ENSAM, Collection « Documents Systèmes Agraires » $\mathrm{N}^{\circ} 9$ du CIRAD, 1989.

FAO. World reference base for soil resources. World Soil Resources Reports, 1998.

Floret C., and R. Pontanier. John Libbey Eurotext, 2000.

Guillaume K., M. Huard, J. Gignoux, A. Mariotti, and Abbadie L. . Oecologia v. 127, p 295-304, 2001.

Lal R., Soil Sci. 165 (57) 2000.

Lata J.-C., K. Guillaume, V. Degrange, L. Abbadie, and R. Lensi. Proc. R. Soc. Lond. B v. 267, n. 595, 2000.

Meyer K.M., K. Wiegand, D. Ward, and A. Moustakas. J. Ecol. v. 95, p.1306-1315, 2007. Manlay R.J., A. Ickowicz, D. Masse, C. Feller, and D. Richard. Agr. Syst. V.79 n. 83, 2004.

Marchal J.Y. Yatenga, nord Haute-Volta : la dynamique d'un espace rural soudanosahélien. ORSTO:, Paris, 1983.

Mazzucato V, Niemeijer D. Rethinking soil and water conservation in a changing society: a case study in eastern Burkina Faso. Tropical Resource Management Papers, 2000.

McMilland D, Nana JB, Sawadogo K. Settlement and Development in River Basin control Zones: Case study Burkina Faso. World Bank Technical Paper n. 200, 1990.

Odum H.T., and B. Odum. Ecol. Eng. V. $20 \mathrm{n}$. 339, 2003.

Reij C. et Thiombiano T. Développement rural et environnement au Burkina Faso : la réhabilitation de la capacité productive des terroirs sur la partie nord du Plateau Central 
entre 1980 et 2001. GTZ-PATECORE, USAID, rapport de synthèse, 2003.

Roose E., V. Kaboré, and C. Guenat. Arid Soil Res. Rehab. V. 13, n. 343, 1999.

Tittonell P., B. Vanlauwe, N. de Ridder, and K.E. Giller. Agr. Syst. v. 94, n. 376, 2007.

Tittonell P., B. Vanlauwe, P.A. Leffelaar, E.C.

Rowe, and K.E. Giller. Agric. Ecosyst. Environ.

V. 110, n. 149, 2005.

Tittonell P., B. Vanlauwe, P.A. Leffelaar, K.D.

Shepherd, and K.E. Giller. Agric. Ecosyst.

Environ. V. 110(2005)166.

Valentin C., J.-L. Rajot, and D. Mitja. Agric.

Ecosyst. Environ. 104 (287), 2004.

Wiegand K., D. Saltz, and D. Ward. Perspect.

Plant Ecol. V. 7, n. 229, 2006. 